\title{
DEPOSITIONS. FACES IN LATE CRETACEOUS-?LOWER TERTIARY DEPOSITS FROM NORTHWESTERN MARANHAO STATE, BRAZIL
}

\author{
RODRIGO DIAS LIMA* \& DILCE DE FATIMA ROSSETTI*
}

\begin{abstract}
Late Cretaceous-?Lower Tertiary deposits from northwestern Maranhao State (northern Brazil) were investigated using facies analysis in outcrops in combination with subsurface data provided from gamma-ray profiles. Four facies associations were recognized in this area and attributed to: a) mouth bar (facies association 1); b) braided fluvial/distributary channel (facies association 2); c) distal mouth bar/crevasse lobe (facies association 3); and d) interdistributary bay/prodelta (facies association 4). Mouth bar deposits consist of well-sorted, fine- to very-fine grained sandstone with a variety of sedimentary structures, mostly including: convolute lamination; overturned foresets; sigmoidal, trough, and tabular cross stratifications; and massive bedding. Growth faults and slumpings are common features associated with these deposits. Braided fluvial/distributary channel deposits are characterized by poorly-sorted, coarse-grained cross-stratified sandstone with sharp, locally concave-up, basal surfaces mantled by lags. Distal mouth bar/crevasse lobe deposits consist of a succession of strata formed by coarsening upward cycles represented by massive and cross-laminated sandstones that are interbedded with mudstones containing abundant plant remains. Finally, interdistributary bay/prodelta deposits include mudstones with abundant plant remains and streaks of silt and very-fine grained sandstones.

The four facies associations described above characterize depositional environments typical of delta settings, an interpretation consistent with the funnel-shaped gamma-ray patterns observed in well logs. Correlation of these deposits with a wave-dominated estuarine system (i.e., Cujupe Formation) exposed in the eastern of Sao Luis Basin led to attribute them to a bayhead delta complex located in the innermost portion of this estuary. The sedimentological and stratigraphic data presented in this paper support the continuity of the Cujupe estuarine system southward of the Ferrer-Urbano Santos Arch. These results thus suggest a paleogeographic reconstruction in which the Sao Luis and Grajau basins behaved as a unique basin at least from the late Cretaceous on.
\end{abstract}

Keywords: estuary, facies analysis, bayhead delta, Cretaceous, stratigraphy

INTRODUCTION Recent sedimentological and sequence stratigraphic studies of late Cretaceous to ?Lower Tertiary rocks exposed in the northeastern margin of the Sao Lufs Basin (Maranhao State) allowed to the recognition of two depositional sequences bounded by regional unconformities (Rossetti 1996a, b). These were formally referred to as the Alcantara and the Cujupe formations of the Itapecuru Group (Rossetti \& Truckenbrodt 1997). Combination of outcrop and subsurface data led to propose that these sedimentary successions formed under strong storm and/or tidal influence, and that they might represent the more seaward portions of incised paleovalley estuarine settings developed during transgressive and highstand stages of relative sea level fluctuation (Rossetti 1996a, b). Subsurface correlation revealed that the paleovalleys would have extended for distances up to $150 \mathrm{~km}$ southwestward. However, there is no geological data characterizing the sedimentological features of the deposits formed headward in these estuaries.

The goal of this paper is to describe the sedimentological aspects of late Cretaceous to ?Lower Tertiary deposits exposed along the BR-316 Road, between Nova Olinda and Zé Doca towns in northwestern Maranhao State. Here, we provide detailed facies and stratigraphic analysis of these strata, and relate them to the more landward areas of the estuarine setting represented by the Cujupe Formation. This approach combines the concepts of facies models within the context of lithostratigraphy and sequence stratigraphy. The beds can not be traced laterally for more than a few hundreds of meters, then we used surface and subsurface data to analyze the strata within a plausible framework for correlations. Although these correlations are inevitably interpretative due to the lack of biostratigraphic information, the results presented in this study furnish additional data to discuss the estuarine model proposed for the Cujupe Formation (Rossetti, 1998). This methodology allowed to analyze the deposits of the study area within the context of a testable wave-dominated estuarine setting developed during the earlier evolutionary stages of an incised paleovalley. In addition, the stratigraphic correlation proposed in this paper leads to reconsider the importance of the Ferrer-Urbano Santos Arch as a geographic barrier between the Sao Luis and Grajau basins during the evolution of this estuarine deposits.

GEOLOGICAL SETTING The studied area is located in the northernmost portion of the Grajau Basin, only a few kilometers south of the Ferrer-Urbano Santos Arch (Fig. 1). This basin has recently been distinguished from the intracratonic Parnafba Basin through the Rio Parnaiba-Xambioa Lineament (Goes 1995) uplifted in the Aptian as a result of the South America and Africa split up. The sedimentary fill of the Grajau Basin is up to $800 \mathrm{~m}$ thick, and consists of lacustrine black shales and fluvio-deltaic sandstones of the Aptian Codó and Grajau formations, respectively. The thickest deposits (circa $450 \mathrm{~m}$ ), however, accumulated during the Albian, and consist of sandstones and mudstones of the Itapecuru Formation. This unit has been traditionally attributed to fluvio-deltaic environments (e.g., Aguiar 1971); however, recent studies in the adjacent Sao Luis Basin have shown that

stratigraphically correctable deposits were formed entirely by storm and/or tidal processes within estuarine depositional settings (Rossetti 1996a,b; Rossetti 1998). Detailed sedimentological and stratigraphic studies in that area led to distinguish two depositional sequences representing portions of incised paleovalleys, which are referred to as the Alcantara (late Albian-Cenomanian) and the Cujupe (late Cretaceous-?Lower Tertiary) formations of the Itapecuru Group (Rossetti and Truckenbrodt 1997). The Alcantara Formation records middle to upper shoreface, foreshore, tidal channel and lagoon/washover depositional settings, which represents a prograding wave-dominated estuarine system formed during the turnaround of the transgressive to highstand systems tracts (Rossetti 1996a, b, 1997). The Cujupe Formation records tidal channel, subtidal bay fill, tidal shoal/sand flat, and tidal delta depositional settings formed in an estuarine setting that changed through time from a wave-dominated to a tide-dominated type as relative sea level rose during transgression and highstand (Rossetti 1998).

DEPOSITIONAL FACIES Four depositional facies assemblage were recognized in the study area (Tables 1 and 2). They include: 1) crossstratified sandstone facies assemblage; 2) deformed to massive sandstone facies assemblage; 3 ) interbedded sandstone and mudstone facies assemblage; and 4) mudrock facies assemblage.

\section{Deformed to massive sandstone (facies assemblage 1)}

This facies assemblage is up to $15 \mathrm{~m}$ thick, being well represented in

Table 1 - Summary of sedimentary facies and sedimentary processes recognized in the study area.

\begin{tabular}{|c|c|c|}
\hline PACIES & DESCKIPTION & SEDIMENTARY PROCESS \\
\hline 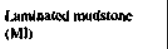 & 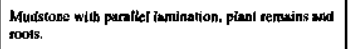 & 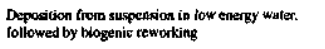 \\
\hline $\begin{array}{l}\text { Deformed sundsione } \\
\text { SSAll }\end{array}$ & 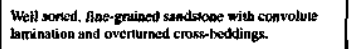 & 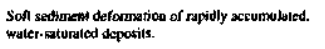 \\
\hline Mastive santamone $(5 \mathrm{~m} r$ & 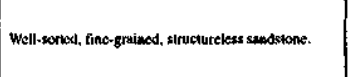 & 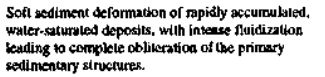 \\
\hline 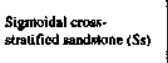 & 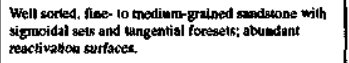 & 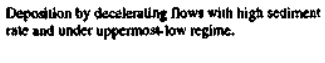 \\
\hline 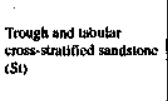 & 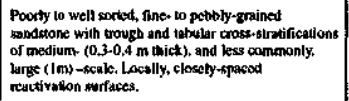 & 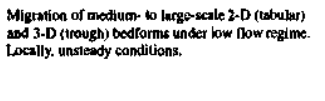 \\
\hline 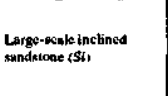 & 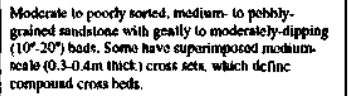 & 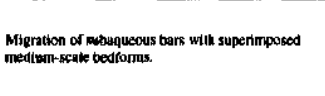 \\
\hline $\begin{array}{l}\text { Cross-tuminulod } \\
\text { tandstootisli }\end{array}$ & 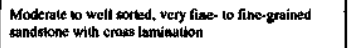 & Migralion of Hipples under fow now regitime. \\
\hline 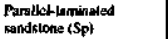 & 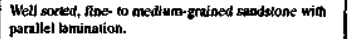 & Deposilton under upper now, flat bod) regine \\
\hline
\end{tabular}

Departamento de Ecologia-Museu Paraense Emflio Goeldi MPEG/CNPq, Av. Magalhaes Barata, 376 CP399 Betem-Para CEP 66040-170 e-mail: rossetti @ museu-goeldi.br 


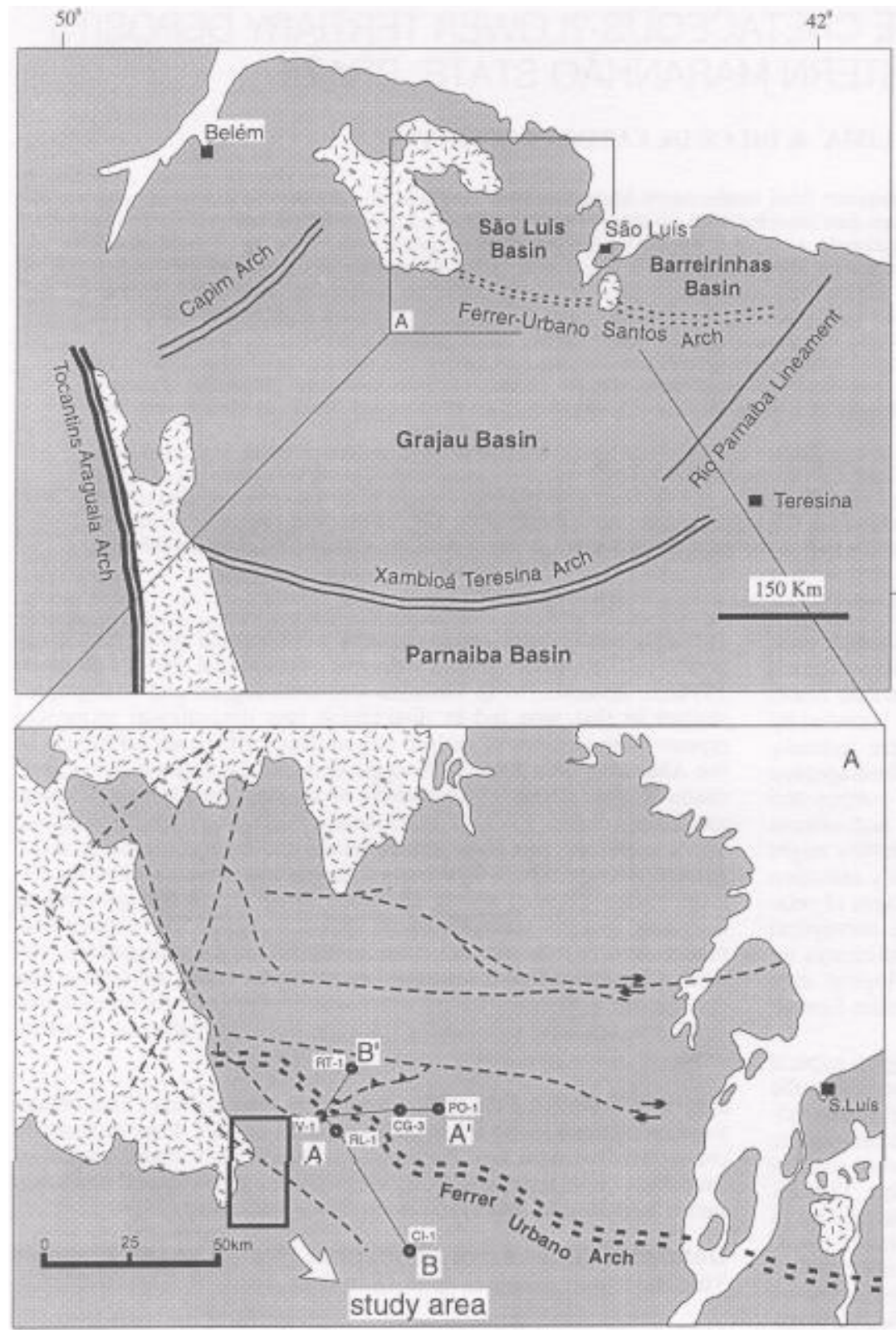

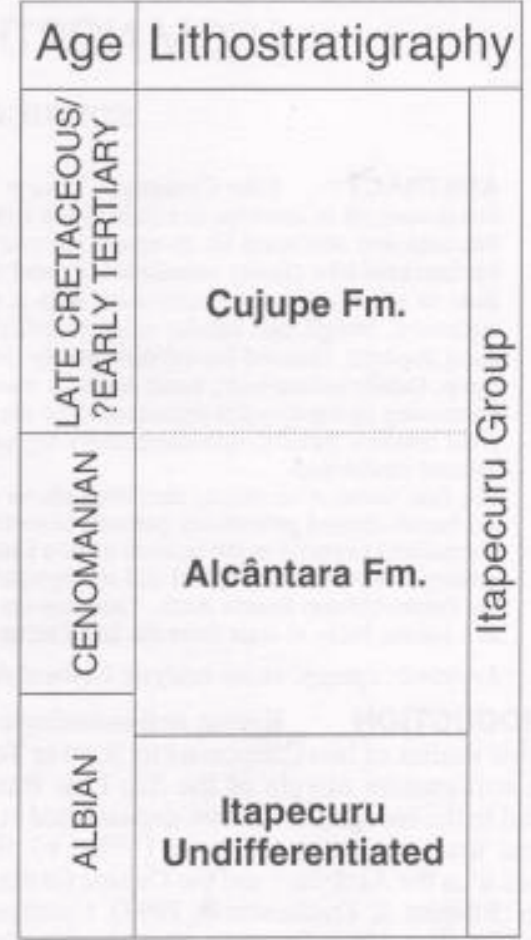

\section{Basement}

- - Structural lineament

C1-10 well

Figure 1 - Location map of study area and simplified stratigraphy of the Itapecuru Group in the São Luís Basin.

Table 2 - Summary of fades assemblages and interpreted depositional environments of the study area.

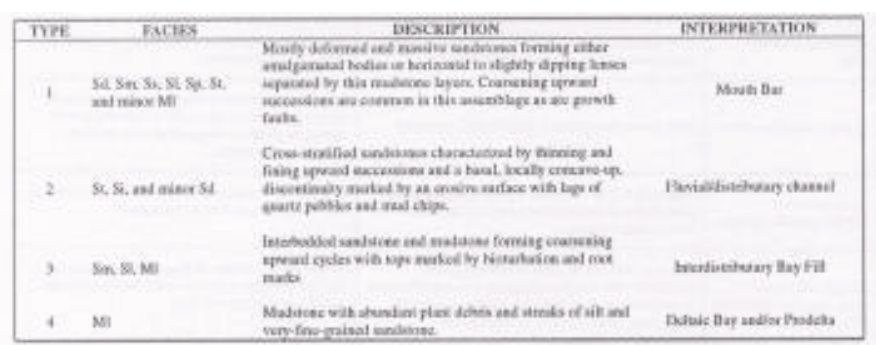

a number of exposures throughout the study area. It consists of micaceous, well-sorted, fine- to very fine-grained, kaolinitic (pseudomorph from feldspar) sandstones. The beds form either amalgamated bodies or horizontal to slightly dipping $\left(<10^{\circ}\right)$ lenses $(0,2$ to $1 \mathrm{~m}$ thick and $50 \mathrm{~m}$ long), the latter separated by thin mudstone layers (Fig. 2 A-C). A variety of facies is recognized within this association, including: i) deformed sandstone (facies $\mathrm{Sd}$ ); ii) massive sandstone (facies $\mathrm{Sm}$ ); iii) sigmoidal cross-stratified sandstone (facies Ss); iv) crosslaminated sandstone (facies SI); v) parallel-laminated sandstone (Sp); vi) trough and tabular cross-stratified sandstone (St); and vi) laminated mudstone (facies Ml).

The deformed sandstones are invariably associated with massive beds, being characterized by convolute laminations with cusps, large scale folds, and overturned foresets. These facies intimately intergrade with medium- to large-scale (up to $1 \mathrm{~m}$ thick) sigmoidal cross sets (Fig. 2 B), which are commonly amalgamated, being defined only by thin mudstone veneers displaying abundant plant remains (facies Ml). The foresets have shapes that change from concave to sigmoidal. They are arranged into packages 5-20 cm thick marked by reactivation surfaces. Reactivation surfaces also occur in association with sigmoidal and medium-scale (0,3-0,4 m thick), trough and tabular cross stratifications. At some places, the sandstones display either cross lamination or alternating cross and parallel laminations. Where sandstone lenses are bounded by mudstone layers, they form coarsening upward cycles (Fig. 2 D).

A remarkable feature of this facies assemblage is the presence of growth faults up to $50 \mathrm{~m}$ wide at the outcrop level. Fault offsets are usually in the order of few tens of centimeters, though larger displacements are observed, when the deformed to massive sandstones abruptly overlie muddier assemblages, delineating spoon-shaped geometries. In addition to the faults, a variety of slumpings also occur in facies assemblage 1 . 

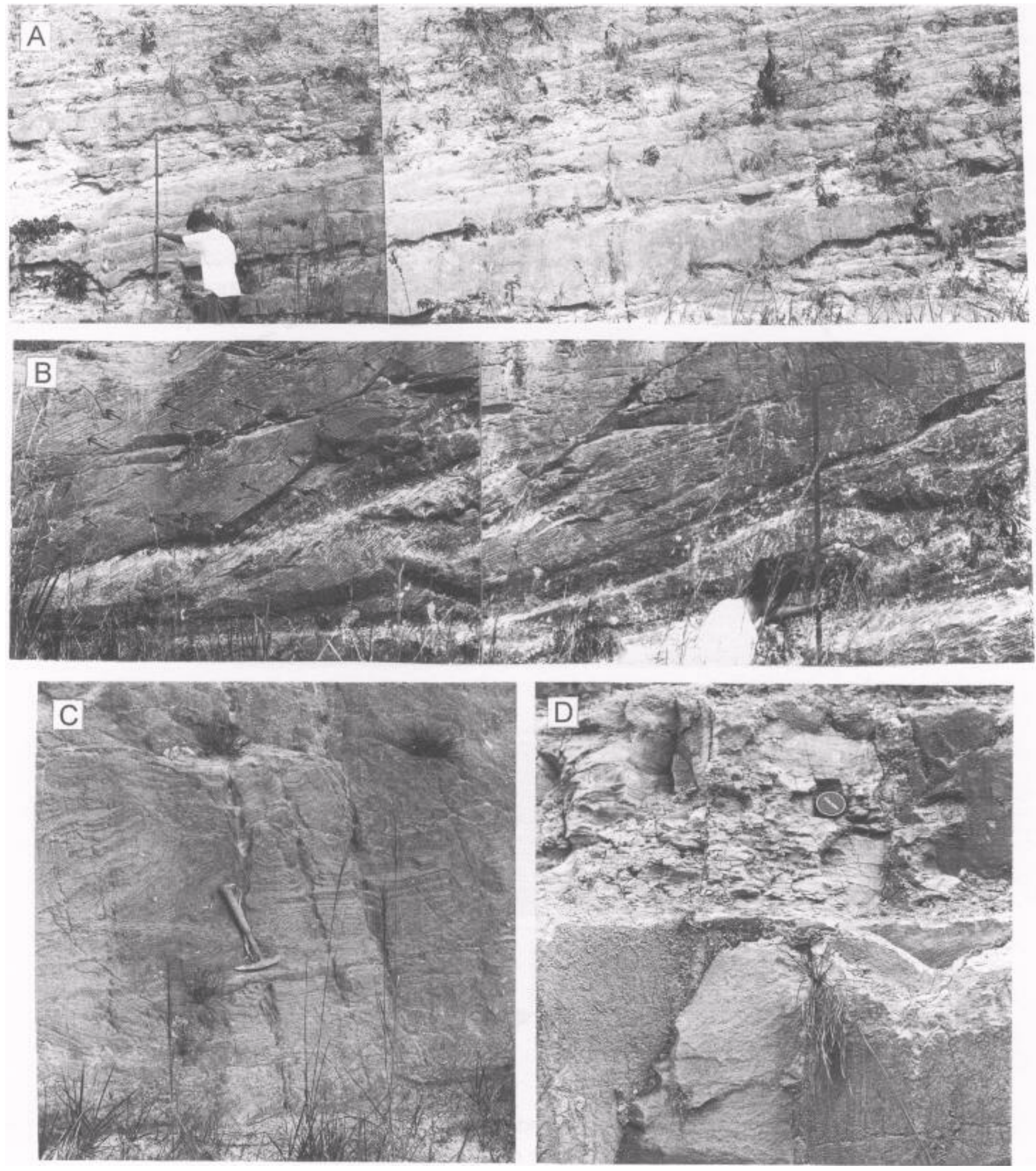

Figure 2 - Fades assemblage 1: Mouth bar deposits, illustrating: A) General view of slightly-dipping sandstone lobes separated by thin mudstone layers; B) Sigmoidal cross stratification (Fades Ss) with abundant reactivation surfaces (arrows); C) Sandstone with convolute lamination (Fades Sd); and D) A detail of sandstone lobes with coarsening upward cycles.

Cross-stratified sandstone (facies assemblage 2) This facies assemblage is up to $10 \mathrm{~m}$ in thickness, and occurs in the northwesternmost portion of the study area, mainly in the vicinity of Nova Olinda town (see Fig. 1). It consists of highly micaceous, very poorly-sorted, coarse-to pebbly grained kaolinitic (i.e., psedomorph from feldspar), cross-stratified sandstones (Fig. 3 A-C). The base of these deposits is marked by an abrupt erosive surface mantled by a pebbly to conglomeratic lag of quartz and mud chips. Where good exposures are available, this basal surface is concave-up defining channel geometries that are up to $40 \mathrm{~m}$ long and $5 \mathrm{~m}$ thick (Fig. $3 \mathrm{~A}$, 

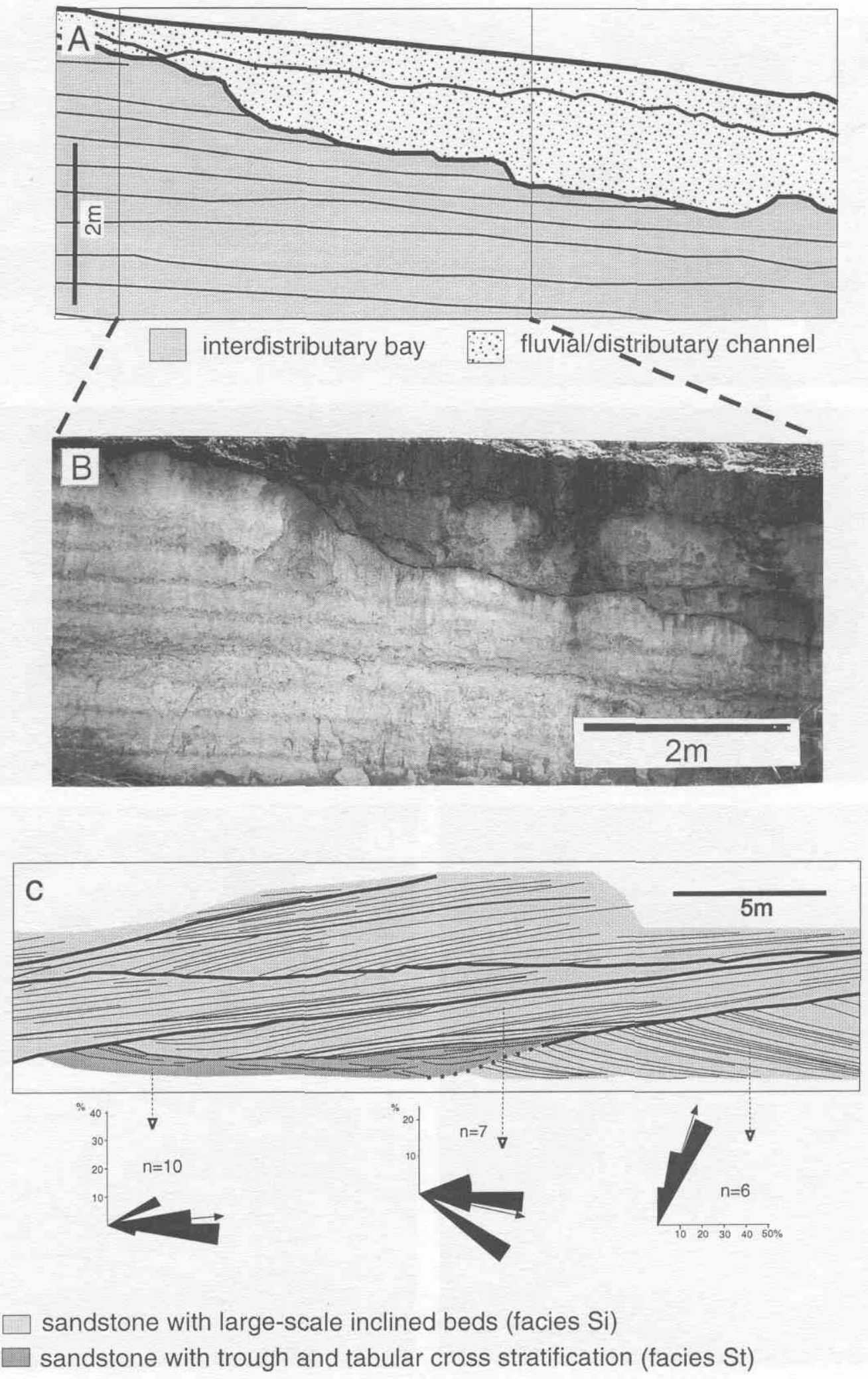

Figure 3 - Fades assemblage 2: Fluvial/interdistributary channel deposits, illustrating: A, B) A line drawing (A) and a photograph (B) with a general view of a sandstone deposit with concave-upward basal erosive surface, which cuts down into inter distributary bay deposits; and C) A detail of a channel deposit with tabular and trough cross stratification at the channel bottom and large-scale inclined beds attributed to transverse to oblique subaqueous bars.

B). The sandstones are arranged into fining and thinning upward cycles. Wood fragments and mudstone intraclasts are disperse in these beds. Three facies are present in facies assemblage 2: i) tabular and trough cross stratified sandstone (facies St), ii) large-scale inclined- stratified sandstone (facies $\mathrm{Si}$ ); and iii) minor deformed sandstone (facies Sd).

The tabular and trough cross stratifications are of medium-(average $30-40 \mathrm{~cm})$ to large- $(1 \mathrm{~m})$ scale and display foreset dip angles of $25^{\circ}$ 

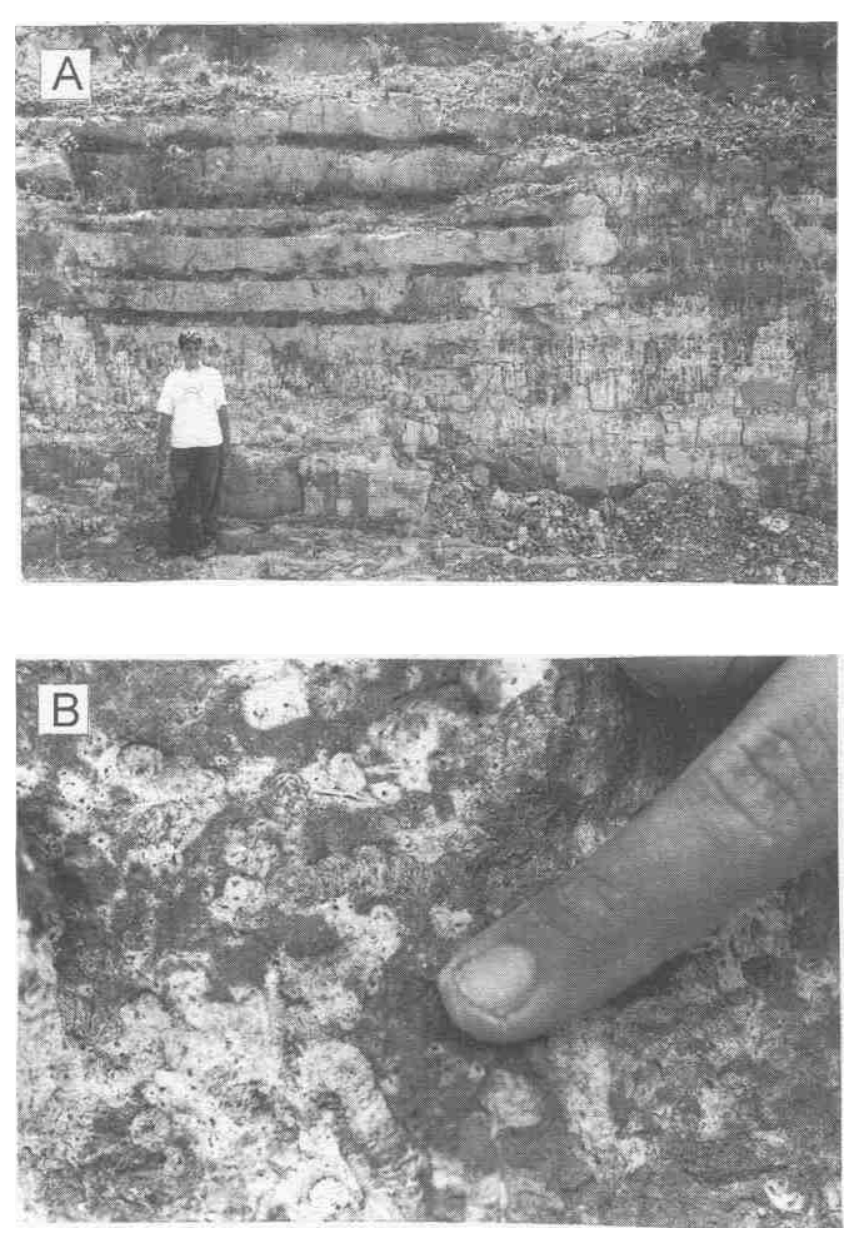
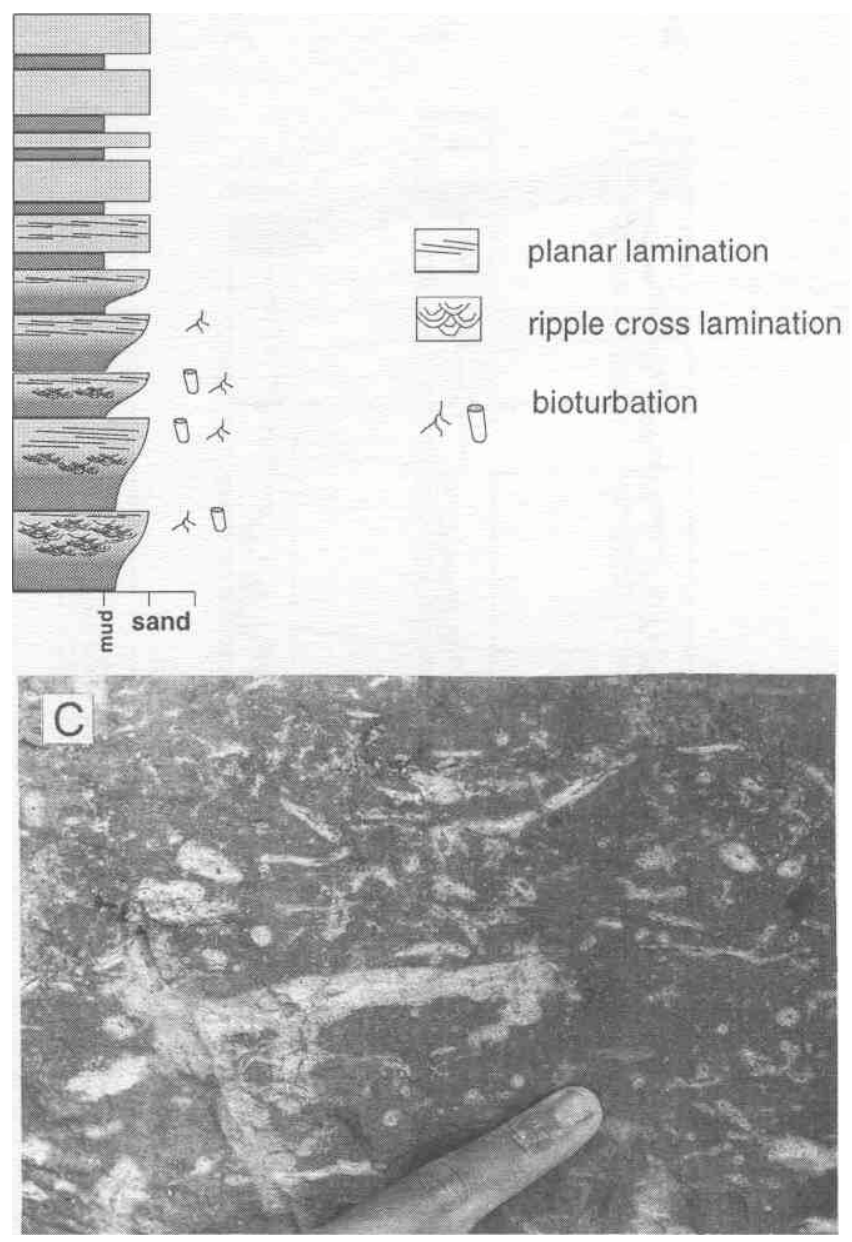

Figure 4 - Facies assemblage 3: Interdistributary bay fill deposits. A) Photograph and vertical profile illustrating interbedded sandstone and mudstone arranged into coarsening upward cycles with bioturbation and root marks. $B, C$ ) Details of the top of one coarsening upward cycle dominated by the trace fossil Taenidium (B) and root marks (C).

(Fig. 3 C). Tabular sets show planar and, less commonly, tangential to concave foresets. Paleocurrent measurements from facies St indicate flows in the east-northeast directions. The large-scale inclined stratifications consist of large-scale (up to $4 \mathrm{~m}$ thick) sets with gently to moderately-dipping $\left(10^{\circ}-20^{\circ}\right)$ foresets. The inclined foresets are either simple or show superimposed, medium-scale descending cross sets, which define compound cross beds. Paleocurrent data from the inclined beds indicate flows that are either parallel or oriented nearly $70^{\circ}$ relative to the surrounding tabular and trough cross strata (facies St). The deformed sandstones (facies Sd) occur only locally and consist of beds with convolute folds and overturned foresets.

Interbedded sandstone and mudstone (facies assemblage 3) This facies assemblage forms packages ranging from 7 to $10 \mathrm{~m}$ thick, which occur throughout the study area closely inter-graded with facies assemblages 1 and 2 (Fig. 3 A, 4 A). It consists of micaceous, well-sorted, Figure 5 - A general view of facies assemblage 4 (deltaic bay/prodelta siltic to very fine-and fine-grained sandstones interbedded with deposits) overlying facies assemblage 1 (mouth bar deposits). mudstones. The following facies are observed in these deposits: i) massive sandstone (facies Sm); ii) cross-laminated sandstone (facies S1); micas, form thin veneers within the mudstones. Streaks of silt and and iii) laminated mudstone (Ml). The sandstones occur in beds up to 1 very-fine grained sandstones are also common in this deposit. $\mathrm{m}$ thick, which laterally pinch out into mudstones containing abundant

plant debris. They have sharp, local symmetrical undulating tops. The SUBSURFACE DESCRIPTION Gamma ray logs from six wells sandstone beds intergrade with muddier lithologies downward, forming located in and surrounding the study area were analyzed in order to help coarsening upward cycles (Fig. $3 \mathrm{~A}$ ) with tops marked by abundant visualizing the geometry and complete the surface paleoenvi-ronment bioturbation and occasional root marks (Fig. 4 B, C). Bioturbation increases interpretation (Fig. 6). This study allowed to correlate the deposits substantially upward, often completely obliterating the primary structures. exposed along the BR-316 Road with an interval up to $45 \mathrm{~m}$ thick The trace fossils Taenidium. Thalassinoides, and Skolithos dominate located in the uppermost portion of the profiles. Subsurface data from throughout these deposits.

this interval led to the recognition of a sharp basal boundary indicated by an abrupt increase in gamma-ray values. This pattern was Mudstone (facies assemblage 4) Packages up to $5 \mathrm{~m}$ thick of traced in all the profiles, defining a surface with a relief of nearly 40 laminated mudstone (facies Ml) containing abundant plant remains overly $\mathrm{m}$. Deposits overlying this basal discontinuity are characterized by a facies assemblages 1 and 3 (Fig. 5). Plant remains, together with bell-shaped gamma-ray pattern, which grades into a funnel-shaped pattern in the upward direction. The relatively close proximity of the 

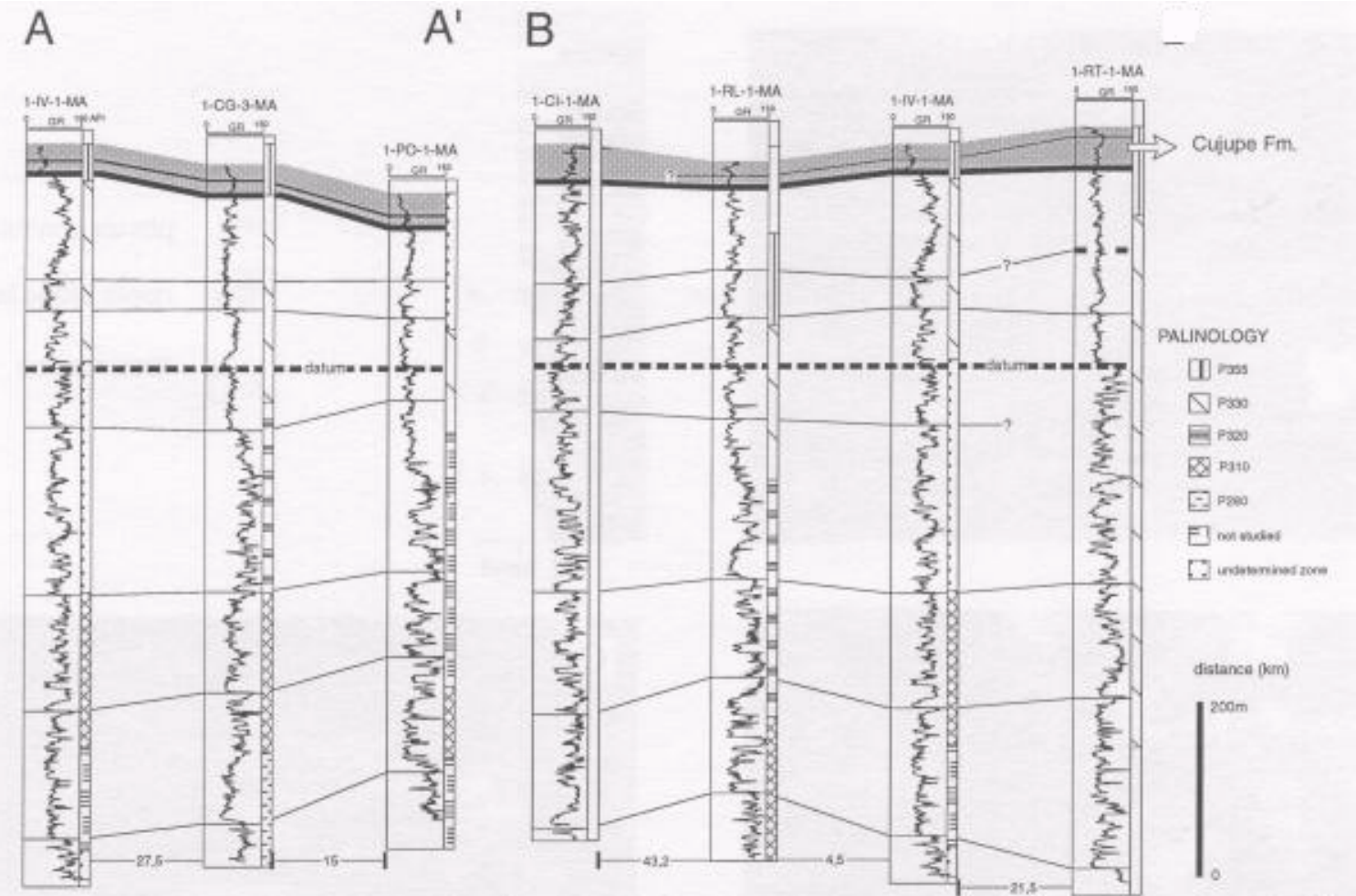

$\mathrm{B}^{1}$

Figure 6 - Subsurface correlation along a dip $\left(A-A^{\prime}\right)$ and a strike $\left(B-B^{\prime}\right)$ section, showing the interval (dark tone) stratigraphically correctable to the Cujupe Formation of the Sao Luis Basin. Note the basal regional discontinuity marked by an abrupt change in gamma-ray signal, which is attributed to a sequence boundary at the paleovaley floor. The interval overlain this surface is charcterized by a bell-and then a funnel-shaped gamma ray pattern, the latter being correlatable to the deltaic deposits exposed in the study area.

exposures to some of the wells (e.g., 1-RL-1-MA, 1-IV-1-MA) allowed to tie the outcrops of the study area to this uppermost interval. Such correlation is consistent with facies interpretation, as discussed in the following.

PALEOENVIRONMENTAL MODEL Integration of surface and subsurface data led to propose a deltaic setting for the deposits exposed in the study area. This interpretation is first suggested by the gamma-ray signal. The funnel pattern observed in the profiles indicates an upward gradual increase in sand content, which is typical of deltas (Coleman \& Prior 1983, Bhattacharya \& Walker 1992). Similar overall tendency prevails in some facies assemblage at the outcrop level (e.g., in the mixed sandstone and mudstone facies assemblage). These characteristics, added to the abundance of plant debris and occasional root marks, revealed deposition in a continental environment experiencing substantial sand influx, which reinforces the deltaic interpretation.

Secondly, the results of facies analysis revealed depositional environments commonly found in deltaic settings. Hence, the deformed to massive sandstone assemblage contains facies accumulated in places undergone to both high sand influx and gravity instabilities, as occurs in mouth bars (e.g., Coleman 1988, Orton \& Reading 1993, Glover \& O'Beirne 1994). Sedimentation rates is high in this type of setting because of the rapid loss in energy that occurs as the flow enters in a standing body of water. Thus, the sigmoidal cross beds of this assemblage are consistent with such interpretation, because these structures indicate deposition by unconfined flows with high suspension load at the boundary between low and upper flow regime (Roe 1987). In addition, mouth bars deposits are characterized by high interstitial water pressure, which leads to intense fluidization and liquefaction (e.g., Mills 1983, Elliott 1986, Van Loon and Brodzikowski 1987, Coleman 1988). Features recording sediment deformation in an unconsolidated or semiconsolidated stage dominate the deposits attributed to mouth bar in the study area (e.g., convolute laminations with folds an overturned foresets, massive beds). In addition, mouth bars are places characterized by intense gravity instabilities promoted by the overloading of sands that prograde into muddy areas (Shepard 1955, Coleman \& Prior 1983, Elliott 1986, Coleman 1988). This process further increased sediment deformation process in the study area, as recorded by the presence of a number of growth faults and slumpings. Mouth bars of many modern an ancient deltaic settings display such features (e.g., Nemec et al. 1988, Edwards 1995, Rider 1978).

The cross-stratified sandstone (facies assemblage 2) is attributed to braided fluvial/interdistributary channel deposits with basis on: 1) the sharp basal contact, locally displaying concave geometry; 2) the presence of a basal lag; 3) the internal fining and thinning upward arrangement; and 4) the dominant coarse-grained to pebbly sand sizes. In addition, the large-scale inclined stratifications (facies $\mathrm{Si}$ ) of these deposits suggest migration of large bars, which are frequently associated with braided fluvial channels (Miall 1977). The presence of compound cross strata is further consistent with such interpretation, once lowsinuosity braided channels is commonly dominated by such composite structures (e.g., Haszeldine 1993). Although the available data are not enough to provide a full interpretation on the nature of these bars, transverse to oblique bars (e.g., Alien 1982; Flint 1983) are suggested by paleocurrent orientation of large foresets either parallel or at angles of nearly $70^{\circ}$ relative to surrounding tabular and trough cross strata (facies St). The latter is attributed to the east-northeast migration of bedforms in the channel floors (Cant \& Walker 1976, Miall 1985). The deposits represented by this facies assemblage probably record fluvial and/or distributary channels.

The mixed sandstone and mudstone facies assemblage records episodic sand input within low energy depositional settings. The root marks at the top of the sandstone beds indicate eventual subaerial exposure. The genetic association with mouth bar e channel facies assemblages suggests that these deposits record progradation of small mouth bars and/or crevasse splays into interdistributary bay areas. Such areas are characterized by mixed sandstone and mudstone deposits having similar coarsening upward successions in many modern and ancient settings (Elliott 1974, Coleman 1988, Bhattacharia \& Walker 1991,1992 , Flint \& Browne 1994). The presence of intense bioturba-tion is suitable with settings experiencing decreasing energy, which represent better habitats for living organisms. The trace fossil Taenidium, together with root marks, indicate the continental-influenced Scoyenia ichnofacies, which is further consistent with the proposed paleoenvironmental interpretation.

The mudstone facies assemblage records mud settling within environments having the lowest energy compared to all the other settings of this depositional system. The great abundance of laminae with plant remains attests to strong continental influence. These characteristics, 
together with the close relationship with fades associations 2 and 3, are consistent with deltaic bay and/or prodeltaic environments (Elliot 1986). Sediments brought by suspensions were trapped into these low energy, deeper areas of the delta setting.

DISCUSSION The results of subsurface gamma-ray data integrated with facies analysis led to attribute the deposits exposed in the study area to mouth bar, fluvial/distributary channel, distal mouth bar/crevasse lobe, and interdistributary bay/prodelta environments, which are typical of deltaic settings. Correlation of gamma ray data leads to suggest that these deposits are equivalent to the Cujupe incised estuarine paleovalley located in the easter Sao Luis Basin (e.g, Rossetti \& Truckenbrodt 1997, Rossetti 1998). If this stratigraphic correlation is accepted, then the discontinuity with relief of nearly $40 \mathrm{~m}$ traced in subsurface would define the bounding surface of the valley floor. The valley fill is represented by the deposits overlying the unconformity. Considering this proposed paleoenvironmental setting, the lowermost bell-shaped portion of the filling must represent fluvial channel deposits formed during the earlier stages of the valley evolution. Fluvial deposits are more likely to be preserved in this proximal areas of the valley because here there is low potential for tidal reworking during eventual transgressions.

The overlying funnel-shaped interval directly correlated with the deltaic deposits of the study area might be attributed to more headward environments of a wave-dominated estuary (Fig. 7). This type of estuary is characterized by an outermost barrier complex, a central bay and a proximal bay-head delta (Clark \& Reinson 1990, Dalrymple et al. 1992, Nichol 1991). A similar system has been proposed for the lowermost portion of the Cujupe Formation in the eastern Sao Luis Basin (Rossetti 1998). This leads to invoke the possibility that the deltaic deposits of the study area might record the innermost portion of this estuary, representing the bayhead delta complex.

The proposed bayhead delta deposits locate circa $150 \mathrm{~km}$ of the estuary mouth, being strongly characterized by continental influence. The sedimentary record does not reveal clearly the influence of tidal currents within these innermost estuarine settings. Depending on the tidal regime, the maximum limit of tidal currents within estuaries might be far beyond the salt water intrusion (Alien \& Posamentier 1993). For instance, the maximum limit of tidal currents in the modern macrotidal Gironde Estuary is $130 \mathrm{~km}$ landward, nearly $50 \mathrm{~km}$ headward of the maximum extension of the saline wedge (e.g., Alien 1991). Considering this modern analogue, tidal currents could have influenced the bayhead delta system of this instance. However, distinguishing a tidal signature in a fluvial-dominated system such as this is problematic. Perhaps the numerous reactivation surfaces observed in the sigmoidal cross beds and in the tabular/trough cross-stratified sandstones (facies Ss and St, respectively) of the mouth bar deposits is a reflex of tidal oscillation. Though not exclusive to, reactivation surfaces are commonly produced by the unsteady nature of tidal processes (e.g., Nio \&

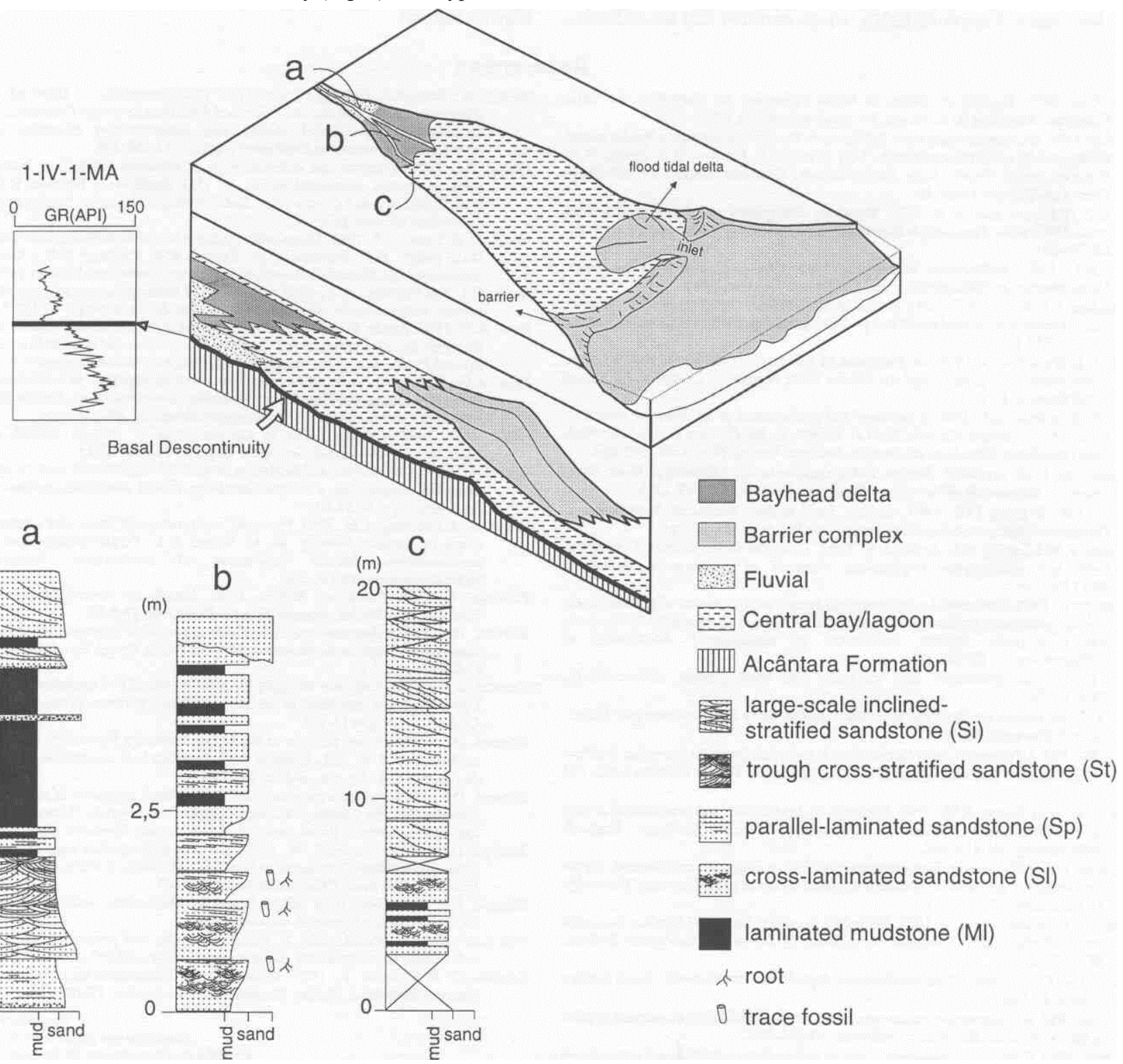

Figure 7 - Schematic diagram illustrating the proposed bayhead delta depositional model for the study area within the context of the Cujupe wave-dominated estuarine system of the eastern Sao Luis Basin. Letters $a, b$ and $c$ indicate measured vertical profiles representative of the different depositional environments recognized in the study area. (See Figure 1 for location of the well J-IV-J-MA). 
Yang 1991). The local abundance and close proximity of these surfaces in the studied strata lead to invoke a similar origin by tidal processes, but unfortunately there is no further evidence sustaining this interpretation.

The correlation of the bayhead delta deposits with the estuarine strata represented by the Cujupe Formation has a wider paleogeographic implication. As mentioned earlier, the study area locates in the northernmost portion of the Grajau Basin, right to the south of the Ferrer-Urbano Santos Arch. This structure is considered a paleogeographic barrier between the Grajau and São Luís basins. The genesis of the Ferrer-Urbano Santos Arch is associated with compressive stress resulting from the clockwise rotation of the Southamerican continent relative to the African continent during the Neocomian (Resende \& Pamplona 1970, Zanotto \& Szatimari 1987). Although the arch seems to have confined sedimentation to the northernmost Sao Lufs Basin in the beginning of its evolution, its role as a limiting feature for sediment accumulation decreased through time. If the strata in the study area formed in a depositional setting genetically related to the estuarine Cujupe Formation, then the arch no longer appears to have constrained sedimentation at this depositional time. That is to say there was a physical connection between the Sao Lufs and Grajau basins from the late Cretaceous, which allowed the northeast estuarine Cujupe paleovalley to develop southwestward into the Grajau Basin, far beyond the limits of the Sao Lufs Basin. Such paleogeographic reconstruction is consistent with earlier works (e.g., Mesner \& Wooldrige 1964, Resende \& Pamplona 1970), which consider that the sedimen- tation during the late Cretaceous transposes the Ferrer-Urbano Santos Arch, and reached a wide area corresponding to the Grajau Basin.

CONCLUSION The late Cretaceous-?Lower Tertiary deposits exposed in the northwest portion of Maranhao State are attributed to a deltaic setting, which is an interpretation based on facies analysis combined to subsurface correlation with an interval characterized by funnel-shaped gamma-ray pattern. The field work led to the recognition of four depositional environments, including mouth bar, fluvial/distributary channel, distal mouth bar/crevasse lobe, and interdistributary bay/prodelta. These deposits are considered to record the innermost bayhead delta complex of the wave-dominated estuarine paleovalley represented by the lowermost deposits of the Cujupe Formation exposed in the eastern Sao Lufs Basin. The continuity of the Cujupe paleovalley southwestward beyond the physical limits of this basin leads to propose that the Ferrer-Urbano Santos Arch did not represent a geographic barrier for sedimentation from the late Cretaceous on. Conversely, the data presented herein strongly support that the Sao Luis Basin was closely connected to the adjacent Grajau Basin located to the south. However, more descriptive field work on other late Cretaceous deposits that surround the study area is still needed to further support this paleogeographic model.

Acknowledgments This paper was supported by grant from the PNPPG/CNPq (Grant N ${ }^{\circ} 400127 / 97-0$ ) and by a CNPq fellowship (Grant 103567/96-8) to the first author. To the Goeldi Museum for its logistic support.

\section{References}

Aguiar, G.A. 1971. Revisao geológica da Bacia Paleozóica do Maranhao. In: SBG, Congresso Brasileiro de Geologia, 25, Sao Paulo. Anais, 1:113-122.

Alien, G.P. 1991. Sedimentary processes and facies in the Gironde estuary: a Recent model for macrotidal estuarine systems. In: D.G. Smith; G.E. Reinson; B.A. Zaitlin; R.A. Rahmani (eds.) Clastic Tidal Sedimentology. Canadian Society of Petroleum Geologists Memoir 16:29-40.

Alien, G.P. \& Posamentier, H.W. 1993. Sequence stratigraphy and facies model of an incised valley fill: The Gironde Estuary, France. Journal of Sedimentary Petrology, 63:378-391.

Alien, J.R.L. 1982. Sedimentary Structures: Their Character and Physical Basis. Developments in Sedimentology 30, Amsterdan, Elsevier, 679 p.

Bhattacharya, J. \& Walker, R.G. 1992. Deltas. In: R.G. Walker \& N.P. James (eds.) Facies Models -Response to Sea Level Change. Geological Association of Canada, Ontario, Canada, $157-177$.

Cant, D.J. \& Walker, R.G. 1976. Development of a braided-fluvial facies model for the South Saskatchewan River and the Battery Point Formation. Canadian Journal of Earth Science, 13:102-119.

Clark, J.E. \& reinson, G.E. 1990. Continuity and performance of an estuarine reservoir, Crystal Field, Alberta, Canada. In: U.H. Barwis; U. Me Pherson \& U.R.J. Studlick (eds.) Sandtones Petroleum Reservoirs, Springer-Verlag, New York, 342-362.

Coleman, J.M. 1988. Dynamic changes and processes in the Mississippi River delta. American Association of Petroleum Geologists Bulletin, 100:999-1015.

Coleman, J.M. \& Prior, D.B. 1983. Deltaic Sand Bodies. American Association of Petroleum Geologists Education Course Note Series no. 15,171 p.

Dalrymple, R.W.; Zaitlin, B.A. \& Boyd, R. 1992. Estuarine facies models: Conceptual basis and stratigraphic implications. Journal of Sedimentary Petrology, 62:1130-1146.

Edwards, M.B., 1995. Differential subsidence and preservation potential of shallow-water Tertiary sequences, northern gulf coast basin, USA. In: A.G. Flint (ed.) Sedimentary Facies Analysis. Special Publication of International Association of Sedimentologists, 22:265-281.

Elliott, T.I974. Interdistributary bay sequences and their genesis. Sedimentology, 21:611-622.

Elliott, T. 1986. Deltas. In: Reading, H.G. (ed.). Sedimentary Environments and Facies. Oxford, Blackwell, 615p.

Góes, A.M. 1995. A Formacdo Poti(Carbonifero Inferior) da Bacia do Parnaiba. Institute de Geociencias, Universidade de Sao Paulo, Sao Paulo, Tese de Doutoramento, 171 $P$.

Glover, B.W. \& O'Beirne, A.M. 1994. Anatomy, hydrodinamics and depositional setting of a Westphalian C lacustrine delta complex, West Midlands, England. Sedimentology, 41:115-132.

Haszeldine, R.S. 1983. Fluvial bars reconstructed from a deep, straight channel, Upper Carboniferous coalfield of northeast England. Journal of Sedimentary Petrology, 53:1233-1248.

Mesner, J.C. \& Wooldridge, L.C. 1964, Maranhao Paleozoic Basin and Cretaceous coastal basins North Brazil. American Association of Petroleum Geologists Bulletin, 48:1476-1512.

Miall, A.D. 1977. A review of the braided-river depositional environment. Earth Science Review, 13:1-62.

Miall, A.D. 1985. Architectural-element analysis: a new method of facies analysis applied to fluvial deposits. Earth Science Review, 22:261-308.

Mills, P.C., 1983. Genesis and diagnostic value of soft-sediment deformation structures- a review. Sedimentary Geology, 35:83-104.
Nemec, W.; Steel, R.J.; Gellerg, U.; Collinson, V.D.; Presthohm, E.; Oxnevad, I.E. 1988. Anatomy of collapsed and re-established delta front in Lower Cretaceous of eastern Spitsbergen: gravitational sliding and sedimentation processes. American Association of Petroleum Geologists Bulletin, 72:454-476.

Nichol, S.L. 1991. Zonation and Sedimentology of estuarine facies in an incised valley, wave-dominated, microtidal setting. In: D.G. Smith; G.E. Reinson; B.A. Zaitlin; R.A. Rahmani (eds.) Clastic Tidal Sedimentology. Canadian Society of Petroleum Geologists Memoir 16:41-58.

Nio S.-D. \& Yang, C.-S. 1991. Diagnostic attributes of clastic tidal deposits: a review. In: D.G. Smith; G.E. Reinson; B.A. Zaitlin; R.A. Rahmani (eds.) Clastic Tidal Sedimentology. Canadian Society of Petroleum Geologists, Memoir 16:3-28.

Orton, G.J., and Reading, H.G., 1993. Variability of deltac processes in terms of sediment supply, with particular emphasis on grain size. Sedimentology, 40:475-512.

Plint, A.G. 1983. Sandy fluvial point-bar sediments from the Middle Eocene of Dorset, England. In:. J.D Collinson \& J. Lewin (eds.)Modern and Ancient Fluvial Systems. Special Publication of International Association of Sedimentologists, 6:355-368.

Plint, A.G. \& Browne, G.H. 1994. Tectonic event stratigraphy in a fluvio-lacustrine, strike-slip setting: the Boss Point Formation (Westphalian A), Cumberland Basin, Maritime Canada. Journal of Sedimentary Research, B64:341-364.

Rider, M.B. 1978. Growth faults in Carboniferous of western Ireland. American Association of Petroleum Geologists Bulletin, 62:2191-2213.

Röe, S.-L. 1987. Cross-strata and bedforms of probable transitional dune to upper-stage plane-bed origin from a Late Precambrian fluvial sandstone, northern Norway. Sedimentology, 34:89-101.

Röe, S.-L. \& Hermansen, M. 1993. Processes and products of large, Late Cambrian sandy rivers in northern Norway. In: M. Marzo \& C. Puigdefabregas (eds.) Alluvial Sedimentation. Special Publication of International Association of Sedimentologists, 17:151-166.

Resende, W.M. \& Pamplona, H.R.P., 1970, Estudo do desenvolvimento do arco Ferrer-Urbano Santos. Boletim Tecnico Petrobras, 13:5-14.

Rossetti, D.F. 1996a. Depositional setting and sequence stratigraphy of the uppermost Itapecuru Formation, northeastern Sao Luis Basin, Brazil. University of Colorado, PhD Thesis, $223 \mathrm{p}$.

Rossetti, D.F. 1996b. Sequence stratigraphic significance of two estuarine valley fills: the Upper Itapecuru Formation in the Sao Luis Basin, northern Brazil. Acta Geologica Leopodinensia 43:111 -125.

Rossetti, D.F. 1997. Facies analisys of the Upper Itapecuru Formation, Sao Luis Basin, northern Brazil. In: M.L. Costa \& R.M. Angelica (eds.) Contribuifdes a Geologia da Amazonia, Calangula, Belem, 241-284.

Rossetti, D.F. 1998. Facies architecture and depositional evolution of an incised-valley estuarine fill: the Cujupe Formation (Upper Cretaceous to ?Lower Tertiary), Sao Luis Basin, northern Brazil. Journal of Sedimentary Research, 68:299-310.

Rossetti, D.F. \& Truckenbrodt, W. 1997. Revisao estratigrffica para os dep6sitos do Albiano-Terciario (?) na Bacia de Sao Luis, Maranhao. Boletim do Museu Paraense Emilia Goeldi, Serie Ciencias da Terra, 9:29-41.

Shepard, P.P. 1955. Delta front valleys bordering Mississippi distributaries. Geological Society of America Bulletin, 66:1489-1498.

Van Loon, A.J. \& Bradzikowski, K. (1987) Problems and progress in the research on soft-sediment deformations. Sedimentary Geology, 50:167-193.

Zanotto, O. \& Szatmari, P., 1987, Mecanismo de rifteamento da por9\$o ocidental da Margem Equatorial. Revista Brasileira de Geociencias, 17:189-195. 